
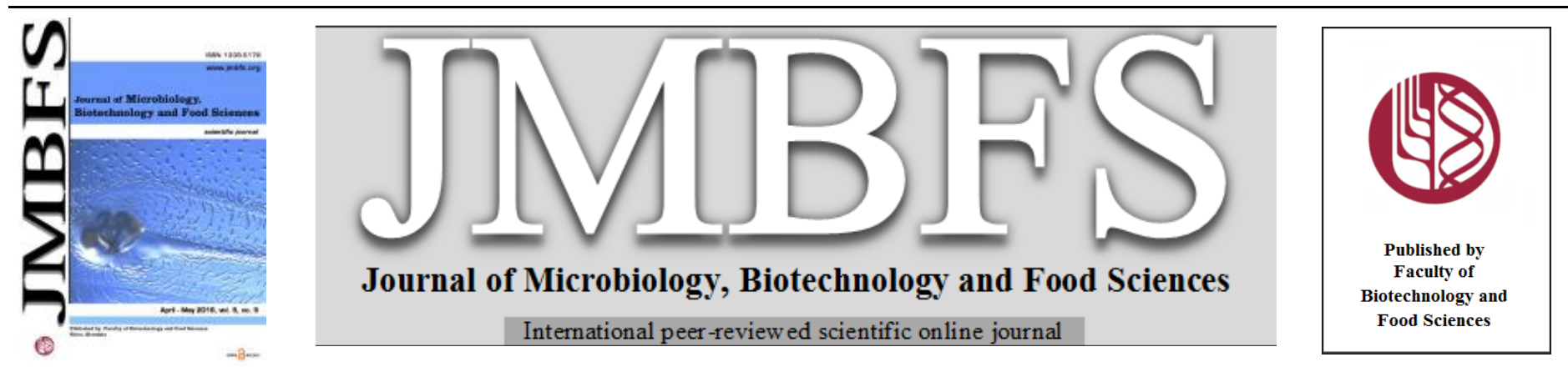

\title{
CHARACTERIZATION OF TYROSINASE ENZYME FROM NATIVE BACILLUS MEGATERIUM SP. STRAIN M36
}

\section{Ebrahim Valipour, Burhan Arikan}

\author{
Address(es): Ebrahim Valipour PhD., \\ Molecular microbiology lab, Biotechnology Department, Institute of Basic and Applied Sciences, Cukuruva University, 01330, Adana, Turkey. Fax: 0090 \\ 3223386070, Tel No: 00905367304074.
}

*Corresponding author: va.cell@yahoo.com

doi: 10.15414/jmbfs.2016.5.5.465-469

\section{ARTICLE INFO}

Received 10. 10. 2015

Revised 26.11. 2015

Accepted 17. 12. 2015

Published 1. 4. 2016

Regular article

OPEN $\partial_{\text {ACCESS }}$

\section{ABSTRACT}

Tyrosinase is a type 3 copper-containing enzyme that catalyzes the conversion of 1-tyrosine to L-DOPA and finally to melanin. In this study tyrosinase enzyme from native Bacillus megaterium sp. strain M36, was produces, characterized and used to produce L-DOPA. The M36 tyrosinase enzyme showed optimum monophenolase and diphenolase activity at $\mathrm{pH} 7.5$ and conserved its maximum activity over than $95 \%$ at pH ranging from 6.5 to 8.0. The M36 tyrosinase enzyme showed optimum monophenolase and diphenolase activity at $40{ }^{\circ} \mathrm{C}$ also, the enzyme conserved $100 \%$ of its original activity at $4-45{ }^{\circ} \mathrm{C}$. The M36 tyrosinase enzyme was inhibited strongly by $\beta$ mercaptoethanol and about $90 \%$ by $5 \mathrm{mmol}$ of EDTA (a chelating agent). Although the enzyme was activated at the presence of $1 \mathrm{mM}$ SDS, it was strongly inhibited at high concentration of SDS (above 15mM). In TLC analysis, the transformation of L-tyrosine to LDOPA was conspicuously detected.

Keywords: Melanin, monophenolase, diphenolase, TLC

\section{INTRODUCTION}

Tyrosinase is a type 3 copper-containing enzyme that has been found widely distributed in microorganisms, plants and animals (Claus and Decker, 2006). Tyrosinase catalyses the hydroxylation of monophenol to o-diphenol (monophenolase or cresolase activity) and the oxidation of diphenol to oquinones (diphenolase or catecholase activity). O-quinones are converted in to melanin by using nonenzymatic steps and molecular oxigene (Decker and Tuczek, 2000). Howard et al., in 1948, elucidated the biosynthetic pathway for melanin formation by tyrosinase enzyme. In mammals, tyrosinase catalyzes the biosynthesis of melanin pigments, which contributes to a fundamental part of the skin protection against UV radiation. It is also related to the browning reactions of fruit and vegetables (Seo et al., 2003). Tyrosinases have several biotechnological applications relying on the ability of the enzymes to oxidize both small phenolic molecules and protein-associated phenolic groups, i.e. the side chain of the amino acid tyrosine. Tyrosinase enzyme has very important role in bioremediation (Marino et al., 201128), production of L-DOPA, the preferred drug for treatment of Parkinson's disease and other antioxidants (having crucial application in medical field) (Xu et al., 2012), food industry (Allouche $\boldsymbol{e t}$ al., 2004), textile industry (Franciscon et al., 2012) and production of melanin (Kumar et al., 2011). Recently, because of increasing application of the tyrosinase enzyme, the interest in the isolation of new tyrosinase enzyme has been increased. Up to present, several tyrosinase enzyme from microbial strains such as Bacillus thuringiensis (El-Shora and Metwally, 2008), Pseudomonas putida F6 (McMahon et al., 2007), Ralstonia solanacearum (HernandezRomero, 2005), Rhizobium etli (Pinero et al., 2007), Streptomyces antibioticus (Marino et al., 2010), Thermomicrobium roseum (Kong et al., 2000), Streptomyces sp. REN-21(Ito and Inouye, 2005), Verrucomicrobium spinosum (Fairhead and Thony-Meyer, 2010) have been isolated and characterized. Most of the strains have multicatalytic functions such as peroxidase and laccases in addition to tyrosinase activity, these characteristics make more restrictions for the strains to be used in industrial and pharmaceutical applications (Dastager $\boldsymbol{e t}$ al., 2006), any way some strains which produce only tyrosinase enzyme has been isolated from soil samples (Freddi $\boldsymbol{e t}$ al., 2006). These strains are appropriate for industrial applications.

The commercial production of tyrosinase enzyme is mostly reported from the common mushroom Agaricus bisporus. Extensive research regarding this enzyme has been carried out using this mushroom tyrosinase. The mushroom's tyrosinase enzyme exhibits relatively low $\mathrm{pH}$ and temperature stability and its purification is relatively hard, as compared to bacterial tyrosinases (Seo et al., 2003). To date, this is the first time that isolation and characterization of a native tyrosinase enzyme from Bacillus megaterium strain was carried out.

\section{MATERIAL AND METHODS}

In this research all material for making medium were bought from sigma and merck. Also the substrate (1-tyrosine) was bought from sigma. According to its information wrote in sigma, L-tyrosine has the following properties; form: fine crystals and fragments, colour: white, molecular weight: $181.19 \mathrm{~g} / \mathrm{mol}$, water solubility: $0.479 \mathrm{~g} / 1$ at $25^{\circ} \mathrm{c}$, formula: $\mathrm{C} 9 \mathrm{H} 11 \mathrm{NO} 3$<smiles>N[C@@H](Cc1ccc(O)cc1)C(=O)O</smiles>

Production and partial purification of the $\mathbf{m} 36$ tyrosinase enzyme

Culture condition for tyrosinase enzyme production by the Bacillus megaterium sp. strain M36had been optimized previously and it was as follow: temperature $\left(36{ }^{\circ} \mathrm{C}\right), \mathrm{pH}(7.0)$, incubation time (16 hour), agitation (170rpm), 1-tyrosine $(0.4 \mathrm{mg} / \mathrm{ml})$, yeast extract $(0.05 \%)$, tryptone $(0.423 \%), \mathrm{NaCl}(3.4 \%)$ and $\mathrm{CuSo} 4$ $(148.4 \mu \mathrm{M})$. The native Bacillus sp.M36 was cultured at optimized culture condition and in order to enzyme extraction, to start with, the cell free extract was prepared then the extract was subjected to ammonium sulfate precipitation and dialysis.

For cell free extract preparation, the medium culture was centrifuged at $6000 \mathrm{~g}$ for 10 min at $4^{\circ} \mathrm{C}$ when $\mathrm{OD}_{530}$ of medium culture was 1.3 , Then the obtained supernatant was stored at $+4^{\circ} \mathrm{C}$ and the pellets were washed twice in ice-cold $50 \mathrm{mM}$ potassium phosphate buffer, $\mathrm{pH}$ 7.0. After that the pellets were resuspended in $0.1 \mathrm{M}$ sodium phosphate $\mathrm{pH} 7.0$ containing an inhibitory bacterial proteases cocktail (1: 4, $\mu 1$ : mg cell mass) and disrupted by sonication. The homogenate was centrifuged at $14000 \mathrm{~g}$ for $15 \mathrm{~min}$. The supernatant achieved both by the previous centrifuge at $6000 \mathrm{~g}$ and by centrifuge at $14000 \mathrm{~g}$ were used as a cell free extract (Lopez-Serrano et al., 2002; McMahon et al., 2007; Michalik et al., 1976). The cell free extract was subjected to precipitation with ammonium sulfate $(40,50,60,70,75,80,85$ and $90 \%$ saturation) for 1 hour with gentle stirring. After fractionation with ammonium sulfate, the precipitated proteins are 
recovered by centrifugation at $12000 \mathrm{~g}$ for 30 minute and are dialyzed against $50 \mathrm{mM}$ sodium phosphate buffer, $\mathrm{pH} 6.8$ with $0.02 \%$ sodium azide, $0.01 \mathrm{mM}$ $\mathrm{CuSO}_{4}$. The fractions were tested to tyrosinase activity and active fractions were stored at $-20^{\circ} \mathrm{C}$ without loss of activity (El-Shora and Metwally, 2008) Protein contents of the samples were determined by Bradford method using bovine serum albumin (BSA) as the standard (Kohashi et al., 2004).

\section{Enzyme assay}

Tyrosinase activity is assayed by using L-tyrosine and L-DOPA as substrates. The appropriate concentration of the enzyme was determined before the enzyme activity was assayed and an aliquot of the enzyme solution is added to a $0.1 \mathrm{M}$ sodium phosphate buffer ( $\mathrm{pH}$ 6.8) containing $1 \mathrm{mM}$ L-tyrosine and L-DOPA, and the formation of dopachrome is monitored by measuring the absorbance at $475 \mathrm{~nm}$ (Rao et al., 2013). The initial rate is used for the calculation of tyrosinase activity. One international unit (IU) of tyrosinase activity is defined as the amount of enzyme required to oxidize $1 \mu \mathrm{mol}$ of L-tyrosine to dopachrom pe minute under the above conditions, which was calculated using the mola extinction coefficient of dopachrome $\left(3600 \mathrm{M}^{-1} \mathrm{~cm}^{-1}\right)$ by the following equation:

$$
\begin{aligned}
& \mathrm{IU} / \mathrm{ml} \sim \mu \mathrm{mol} / \mathrm{min} / \mathrm{ml}) \\
& =\frac{\text { absorption } / \mathrm{min} \cdot \text { assay volume }(\mathrm{ml}) \cdot \text { dilution factor } \cdot 10000}{\varepsilon_{\mathrm{nm}}\left(1 \cdot \mathrm{mol}^{-1} \mathrm{~cm}^{-1}\right) \cdot 1 \mathrm{~cm} \cdot \text { enzyme volume }(\mathrm{ml})}
\end{aligned}
$$

\section{Effect of pH and temperature on enzyme activity and stability}

For this purpose, $200 \mu \mathrm{l}$ of enzyme solution (protein content, $0.05 \mathrm{mg} / \mathrm{ml}$ ) was added to $1800 \mu \mathrm{l}$ buffer containing $1 \mathrm{mM}$ of L-dopa for diphenolase and $1 \mathrm{~mm}$ of 1 tyrosinae for monophenolase activity and incubated for $45 \mathrm{~min}$. The effect of $\mathrm{pH}$ on monophenolase activity was investigated by analyzing the activity at different $\mathrm{pH}$ values $(\mathrm{pH} 4,5,6,7,8,9,10,11$ and 12$)$ and for diphenolase activity $\mathrm{pH}(4$ 7.5) were tested because L-DOPA spontaneously converted to dopachrome at $\mathrm{pH}$ values above 7.5. $\mathrm{pH}$ value in which the enzyme showed maximum relative activity was determined as optimum $\mathrm{pH}$ for the enzyme activity (Burhan $\boldsymbol{e t} \boldsymbol{a l}$., 2003; McMahon et al., 2007).

Also, the enzyme activity was analyzed at a range of temperatures from 10 to $70^{\circ} \mathrm{C}(10,20,30,40,50,60$ and 70$)$ and the temperature showing maximum relative activity was determined as an optimum temperature for the enzyme activity. In order to ascertain of the temperature stability, the enzyme solutions in different tubes are incubated at various temperatures in the range from $0^{\circ} \mathrm{C}$ to $70^{\circ} \mathrm{C}$ for 2 hour then residual activity is assayed in enzyme assay condition (Liu et al., 2004).

\section{Effect of detergents on enzyme activity}

To examine the effects of sodium dodecyl sulphate (SDS), ethylene diamine tetraacetic acid (EDTA), Urea, Tween-80, TritonX-100, $\beta$-Mercaptoethanol and PMSF are analyzed by incubating enzyme in the presence of these detergents and substrate (Aygan et al., 2009; Caf et al., 2012).

\section{Kinetic study of M36 tyrosinase enzyme}

The initial rate of enzyme reaction for 1-tyrosine and L-DOPA was determined at various concentrations. The resulting data was analyzed and the $\mathrm{K}_{\mathrm{m}}$ and $\mathrm{V}_{\max }$ values are calculated by Michaelis-Menten and Hill equation $\mathrm{v}_{\mathrm{i}}=\frac{\mathrm{v}_{\max }[\mathrm{S}]}{\mathrm{k}_{\mathrm{m}}+[\mathrm{s}]}$ and Lineweaver-burk equation $\frac{1}{v_{i}}=\frac{K_{m}}{V_{\max }} \frac{1}{[s]}+\frac{1}{v_{\max }}$ (Mc Mahon et al., 2007; 45 Zanjani et al., 2009). After addition of $200 \mu \mathrm{l}$ of enzyme solution (protein content, $0.05 \mathrm{mg} / \mathrm{ml}$ ) to potassium phosphat $(50 \mathrm{mM}, \mathrm{pH}, 7)$ containing various concentrations ranging from 0.02 to 0.8 for tyrosine and 0.06 to 2.0 for L-DOPA, the reaction medium with L-DOPA and with L-tyrosine was incubated at room temperature for $30 \mathrm{~min}$ and $45 \mathrm{~min}$, respectively. After that the reaction medium with L-tyrosine was diluted 5 times and reaction medium with L-DOPA was diluted 10 time and both of them was subjected to study of $\mathrm{OD}_{475}$ by spectrophotometer. The obtained data was used to calculation of velocity.

\section{Electrophoretic study}

The enzyme solution was loaded in several well of Non-denaturing PAGE (8\% $\mathrm{w} / \mathrm{v}$ ) and after separating protein bands, a single lane of the gel was sliced out of the gel using a clean scalpel. The tyrosinase enzyme related band was stained by placing the gel slice in substrate solution (1-tyrosine $(0.1 \mathrm{mg} / \mathrm{ml})$ and $\mathrm{CuSO}_{4}$ $(50 \mu \mathrm{M})$ in phosphate buffer $(0.1 \mathrm{M}, \mathrm{pH} 7))$ for $60 \mathrm{~min}$. The formation of a darkbrown band indicated the position of the tyrosinase enzyme. The remaining lanes of the gel were placed in $50 \mathrm{mM}$ phosphate buffer, $\mathrm{pH} 7.0$. Using the activity stained lane as a guide to the location of tyrosinase, the corresponding band was sliced out of the unstained lanes. The gel slice was homogenized and resuspended in a $50 \mathrm{mM}$ phosphate buffer and left overnight at $4{ }^{\circ} \mathrm{C}$. The gel suspension was centrifuged at $12000 \mathrm{~g}$ for $10 \mathrm{~min}$ to remove remaining gel fragments and the obtained supernatant was subjected to SDS-PAGE (12\%) analysis for determination of the tyrosinase enzyme molecular weight (Arikan, 2008)

\section{Thin layer chromatography analysis of the reaction mixture}

The conversion of L-tyrosine to L-DOPA by M36 tyrosinase enzyme was analyzed by thin layer chromatography. For this purpose, phenol-water system $(75: 25)(\mathrm{w} / \mathrm{v})$ was used as a mobile phase and $3 \%$ ninhydrin in n-butanol as spray and staining reagent. Besides of TLC analysis, (Rani et al., 2007; Raval et al., 2012).

\section{Statistical analysis}

All experiments were conducted in three replicates; data generated were subjected to statistical analysis using Microsoft Excel and presented as mean_SE.

\section{RESULT AND DISCUSSION}

\section{Preparation of the M36 tyrosinase enzyme}

The enzyme was precipitated by ammonium Sulfate $85 \%$ and centrifugation at $13000 \mathrm{~g}$ and dialyzed against $50 \mathrm{mM}$ sodium phosphate buffer $(\mathrm{pH} 6.8$ containing $0.02 \%$ sodium azide and $0.01 \mathrm{mM} \mathrm{CuSO}_{4}$ ).

\section{Effect of $\mathrm{pH}$ and temperature on enzyme activity and stability}

The result of this research showed that the M36 tyrosinase enzyme had maximum monophenolase and diphenolase activity at $\mathrm{pH}, 7.5$ (Figure 1). This result was in accordance with tyrosinase enzyme originated from Streptomyces $s p$. REN-21 (pH 7.0) (Ito and Inouye, 2005), Rhizobium etli CFN42 (pH 7.5) (Pinero et al. 2007) and Pseudomonas putida F6 ( $\mathrm{pH}$ 7.0) (McMahon et al., 2007) notwithstanding, the tyrosinase enzyme from B. thuringiensis (Liu et al., 2004) and $T$. roseum (Kong et al., 2000) have shown to have maximum activity at 9.0 and 9.5, respectively. The M36 tyrosinase enzyme could conserve its maximum activity over than $95 \%$ at $\mathrm{pH}(6.5-8.0)$. Before $\mathrm{pH}(6.5)$ and above $\mathrm{pH}(8.0)$ the activity and stability of the enzyme was dropped. These findings are similar to the finding of Shuster and Fishman (2009).

The tyrosinase enzymes have two cupper in its active site and each of the two metal atoms; $\mathrm{Cu}_{\mathrm{A}}$ and $\mathrm{Cu}_{\mathrm{B}}$, of the active site are coordinated by three conserved histidines which are located in a 'four $\alpha$-helix bundle' (Claus and Decker, 2006). The $\alpha$-helix is structured by hydrogen bonds. Generally changing of $\mathrm{pH}$ value (extremely basic or acidic) causes changes in the charge of $\mathrm{H}$-bond donor and acceptor groups, it can rearrange the H-bonds and change the conformation/folding of the protein.

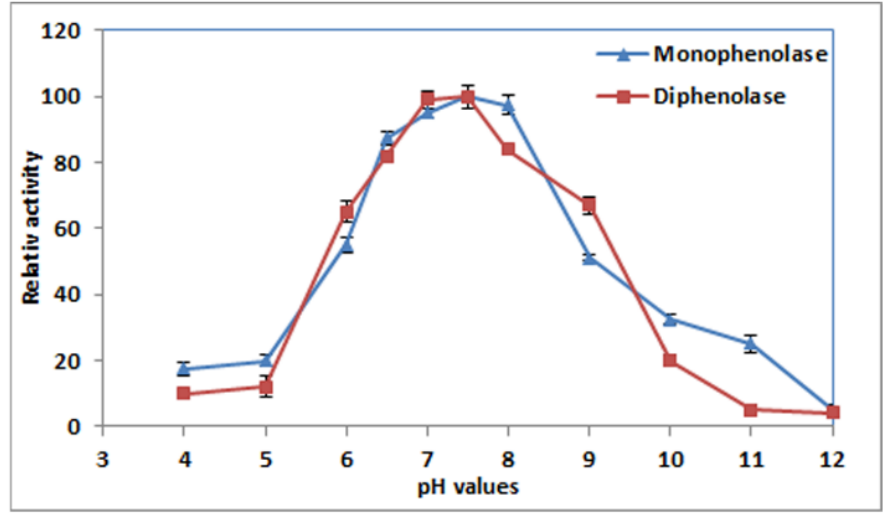

Figure 1 Effect of $\mathrm{pH}$ on activity and stability of the Bacillus megaterium M36 tyrosinase enzyme (monophenolase). The enzyme showed maximum activity $(0.52 \mathrm{IU})$ at $\mathrm{pH}=7.5$ and $97.5 \%$ of its maximum activity at $\mathrm{pH}=8.0$. At $\mathrm{pH}$ lower than 6.5 and higher than 8.0 the activity of the enzyme was steeply decreased.

The M36 tyrosinase enzyme showed optimum monophenolase and diphenolase activity at $40{ }^{\circ} \mathrm{C}$ also, the enzyme conserved $100 \%$ of its original activity at $4-45$ ${ }^{\circ} \mathrm{C}$ (Figure 2). The monophenolase and diphenolase activity of the enzyme was deeply decreased at temperature below $30^{\circ} \mathrm{C}$ and above $55^{\circ} \mathrm{C}$, probably this result was related to that, the tyrosinase enzyme has mostly composed from $\alpha$ helix, on the other hand $\alpha$-helix is more flexible than the others structures. This result was more or less closed to other investigations.

The M36 tyrosinase enzyme showed up to $95 \%$ activity at temperature ranges from $35{ }^{\circ} \mathrm{C}-45^{\circ} \mathrm{C}$, in contrast to this, the activity of tyrosinase enzyme from $P$. putida F6 (McMahon et al., 2007) has been decreased dramatically at temperature above $30^{\circ} \mathrm{C}$ and the enzyme of Streptomyces michiganensis DSM (Philipp et al., 1991) has showed optimum activity at $33^{\circ} \mathrm{C}$. Moreover there is some reported tyrosinase enzymes whit higher optimum temperature. Also the 
M36 tyrosinase enzyme was different with the tyrosinase from Rhizobium etli CFN42 $\left(50^{\circ} \mathrm{C}\right)$ (Pinero et al., 2007), Bacillus $(H R 03)\left(55^{\circ} \mathrm{C}\right)$ (Dalfard et al., 2006), Bacillus thuringiensis $\left(75^{\circ} \mathrm{C}\right)$ (El-Shora, Metwally, 2008) and Thermomicrobium roseum $\left(70^{\circ} \mathrm{C}\right)$ (Kong et al., 2000). The M36 tyrosinase enzyme conserved its original activity at $45^{\circ} \mathrm{C}$, contrary to this Trichoderma reesei (Cura et al., 2010) tyrosinase started to lose its activity relatively quickly at temperature above $30^{\circ} \mathrm{C}$.
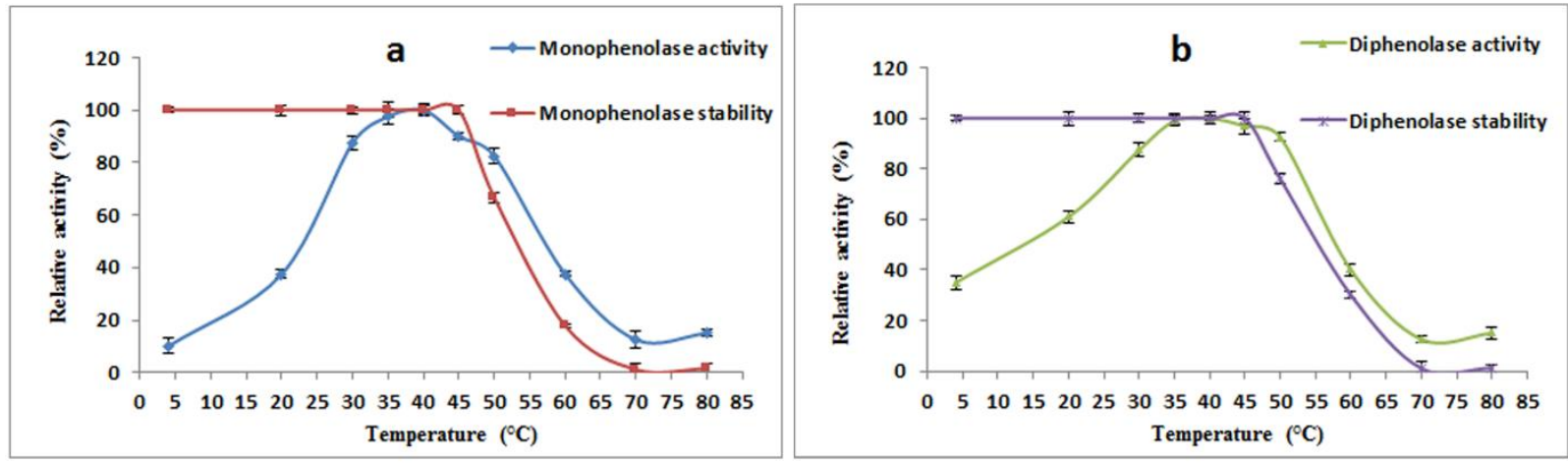

Figure 2 Effect of temperature on a) monophenolase (L-tyrosine as a substrate) and b) diphenolase activity (L-DOPA as a substrate) of the Bacillus megaterium M36 tyrosinase enzyme. The enzyme showed maximum monophenolase (0.56IU) and maximum diphenolase activity $(0.62 \mathrm{IU})$ at $40^{\circ} \mathrm{C}$. Both of the monophenolase and diphenolase activity were conserved $100 \%$ at temperature $0-45^{\circ} \mathrm{C}$, after that the enzyme loosed its activity.

\section{Effect of detergents on enzyme activity}

The M36 tyrosinase enzyme was studied in presence of various inhibitors (Figure 3a). The enzyme was inhibited strongly by $\beta$-mercaptoethanol. $\beta$ mercaptoethanol is a reducing agent which inhibit dopachrom and melanin synthesis by reducing qinones (an intermediate) to L-DOPA. Similar results were obtained for Bacillus megaterium tyrosinase (Shuster and Fishman, 2009), and Thermomicrobium roseum tyrosinase (Kong et al., 2000) that was completely inhibited by $\beta$-mercaptoethanol ( $1 \mathrm{mmol})$. The M36 tyrosinase was inhibited about $90 \%$ by $5 \mathrm{mM}$ EDTA (a chelating agent). The agent can inhibit the enzyme by chelating of $\mathrm{Cu}$ from its active site. Similarly Bacills megaterium tyrosinase was inhibited up to $27 \%$ by $1 \mathrm{mM}$ EDTA (Shuster and Fishman, 2009) and Bacillus (HRO3) tyrosinase enzyme was partially inhibited by $1 \mathrm{mM}$ EDTA
(Dalfard et al., 2006). In contrast to the result of this research tyrosinase enzyme from Bacillus thuringiensis (El-Shora and Metwally, 2008) was activated at high concentration EDTA from 200 to $400 \mathrm{mM}$. Effect of different concentration of SDS (0.2-30mM) on the M36 tyrosinase enzyme was studied. Although the enzyme was activated at the presence of $1 \mathrm{mM}$ SDS, it was strongly inhibited at high concentration of (above $15 \mathrm{mM}$ ) SDS (Figure 5b). Previously, activating effect of SDS on tyrosinase enzyme from Xenopus laevis (Wittenberg and Triplett, 1985), A. bisporus (Espin and Wichers, 1999), Bacillus sp. (Dalfard et al., 2006) and Bacillus megaterium (Shuster and Fishman, 2009) has been reported which was in agreement with our result. According to the paper published by Gandia-Herrero, although, active site of enzyme is not affected by SDS; a stepwise conformational change affected the enzyme activity by increasing accessibility of its active site to the substrate (Gandía-Herrero et al., 2005).
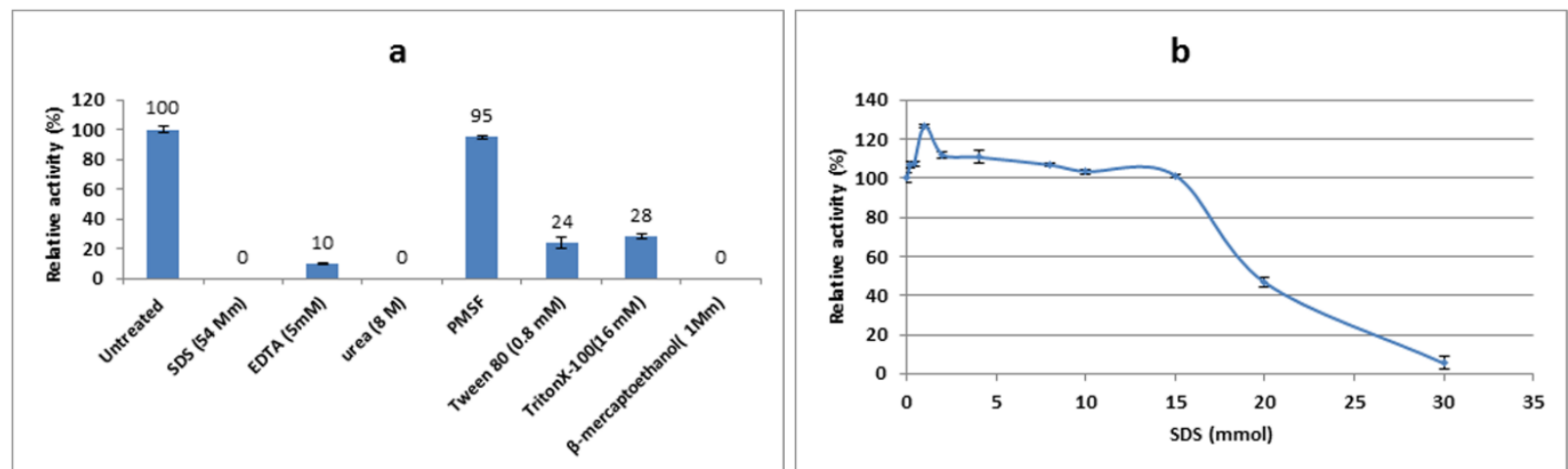

Figure 3 a) Effect of inhibitors on Bacillus megaterium M36 tyrosinase activity. The activity of the sample containing the enzyme without any of the additives was considered as control $(100 \%)$. b) Effect of SDS concentration (w/v) on the Bacillus megaterium M36 tyrosinase activity. The enzyme showed maximum activity $(126.6 \%)$ at the presence of $1 \mathrm{mM}$ of SDS and its activity was gradually decreased at the SDS concentration more than $1 \mathrm{mM}$, so that it reached to $5.3 \%$ at concentration of $30 \mathrm{mM}$. Sample having no SDS in reaction mixture was considered as a control (100\%)

\section{Production of L-DOPA from L-tyrosine}

In TLC analysis, the transformation of L-tyrosine to L-DOPA was conspicuously detected. Ascorbic acid, used to prevent further oxidation of L-DOPA, did not give interfering spots (Figure 4)

\section{Kinetic study of M36 tyrosinase enzyme}

The M36 tyrosinase enzyme was shown to obey Michaelis-Menten kinetics when L-tyrosine and L-DOPA was used as a substrate. The $\mathrm{K}_{\mathrm{m}}$ value of M36 tyrosinase for l-tyrosine $(0.15 \mathrm{mM})$ was lower than L-DOPA $(0.58 \mathrm{mM})$. The obtained $\mathrm{V}_{\mathrm{m}}$ was $1.7 \mu \mathrm{M} \cdot \mathrm{min}^{-1} \cdot \mathrm{ml}^{-1}$ for l-tyrosine and $6.2 \mu \mathrm{M} \cdot \mathrm{min}^{-1} \cdot \mathrm{ml}^{-1}$ for L-DOPA. $\mathrm{K}_{\mathrm{m}}$ value of M36 tyrosinase enzyme was similar to the previously reported $K_{m}$ values with the 1-tyrosine, for example ; 0.2mM for Agaricus bisporus (Selinheimo et al. 2009) and $0.19 \mathrm{mM}$ for Rhizobium etli CFN42 (Cabrera-Valladares et al., 2006), also it is higher than the value $(0.075 \mathrm{mM})$ reported for Bacillus megaterium (Shuster and Fishman, 2009) and it is less than the values $0.563 \mathrm{mM}, 1 \mathrm{mM}, 0.421 \mathrm{~mm}$ reported for Bacillus huringiensis (El-Shora and Metwally, 2008) , Streptomyces sp. REN-21(Ito and Inouye, 2005) and Verrucomicrobium spinosum (Fairhead and Thony-Meyer, 2010), respectively. The $\mathrm{K}_{\mathrm{m}}$ value of M36 tyrosinase enzyme for L-DOPA was higher than $\mathrm{K}_{\mathrm{m}}$ value of tyrosinase from Agaricus bisporus $(0.17 \mathrm{mM})$ (Selinheimo et al., 2009), $P$. putida F6 (0.33) (McMahon et al., 2007) and Bacillus megaterium (0.35mM) (Shuster and Fishman, 2009) for the same substrate, but it was lower than $\mathrm{K}_{\mathrm{m}}$ values of tyrosinase from Trichoderma reesei $(7.5 \mathrm{mM})$ (Selinheimo et al, 2009), Rhizobium etli CFN42 (2.44mM) (Cabrera-Valladares et al., 2006), Streptomyces antibioticus $(8.9 \mathrm{mM})$ (Marino et al., 2011), Streptomyces castaneoglobisporus ( $8 \mathrm{mM}$ ) (Kohashi et al., 2004) and Verrucomicrobium spinosum $(7 \mathrm{mM})$ (Fairhead and Thony-Meyer, 2010). 


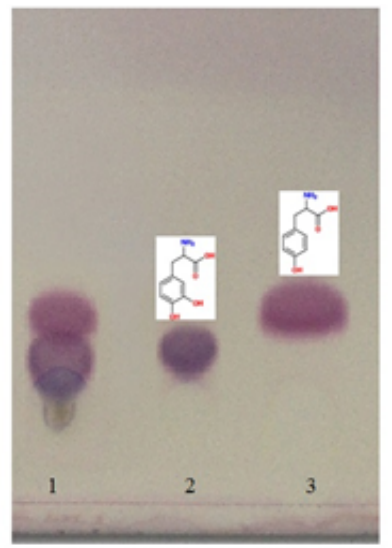

Figure 4 TLC analysis of L-tyrosine conversion to L-DOPA by Bacillus megaterium M36 tyrosinase enzyme

\section{Electrophoresis and enzymatic activities in gel}

After dialysis, tyrosinase M36 was electrophoresed by using native polyacrylamide gel (8\%), after specific staining, a distinct band was detected. by extracting of the tyrosinase enzyme from native gel using the method mentioned in material methods, and the enzyme was subjected to SDS-PAGE (12\%) analysis. This analysis showed almost $34 \mathrm{kDa}$ bond of the enzyme (Figure 5) This result was similar to the result of Shuster and Fishman (2009) who have demonstrated the tyrosinase from Bacillus megaterium to be almost $35 \mathrm{kDa}$.

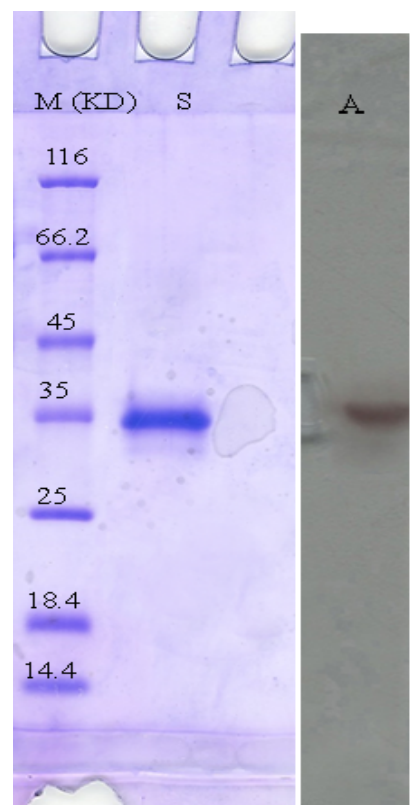

Figure 5 Electrophoresis analysis of the Bacillus megaterium M36 tyrosinase Enzyme. Lane (A) shows tyrosinase activity, lane (T) shows the enzyme molecular weight almost $34 \mathrm{KDa}$, almost $15 \mu \mathrm{g}$ of protein was loaded, lane (M) shows protein marker.

Acknowledgments: This research was supported by the TUBITAK research fund (No. 114Z065) and BAP research fund in CUKURUVA UNIVERSITY of Turkey (No. FEF2013D33).

\section{REFERENCES}

Ali, S., Shultz, J.L., Ikram, U.1.H. (2007). High performance microbiological transformation of L-tyrosine to L-dopa by Yarrowia lipolytica NRRL-143. BMC Biotechnol 7:50. http://dx.doi.org/10.1186/1472-6750-7-50

Allouche, N., Damak, A., Ellouz, R., \& Sayadi, S. (2004). Use of whole cells of Pseudomonas aeruginosa for synthesis of the antioxidant hydroxytyrosol via conversion of tyrosol. Applied and Environmental Microbiology, 70(4), 21052109. http://dx.doi.org/10.1128/aem.70.4.2105-2109.2004

Arikan, B. (2008). Highly thermostable, thermophilic, alkaline, SDS and chelator resistant amylase from a thermophilic Bacillus sp isolate A3-15. Bioresource Technology, 99(8), 3071-3076. http://dx.doi.org/10.1016/j.biortech.2007.06.019

Aygan, A., \& Arikan, B. (2009). Production and characterization of multifunctional endoxylanase by Bacillus sp X13. Turkish Journal of Biology, 33(3), 231-237.
Burhan, A., Nisa, U., Gokhan, C., Omer, C., Ashabil, A., \& Osman, G. (2003) Enzymatic properties of a novel thermostable, thermophilic, alkaline and chelator resistant amylase from an alkaliphilic Bacillus sp isolate ANT-6. Process Biochemistry, 38(10), 1397-1403. http://dx.doi.org/10.1016/s0032 9592(03)00037-2

Cabrera-Valladares, N., Martinez, A., Pinero, S., Lagunas-Munoz, V. H., Tinoco, R., de Anda, R., Gosset, G. (2006). Expression of the melA gene from Rhizobium etli CFN42 in Escherichia coli and characterization of the encoded tyrosinase. $\begin{array}{llll}\text { Enzyme and Microbial Technology, } & 38(6), & 772-779 .\end{array}$ http://dx.doi.org/10.1016/i.enzmictec.2005.08.004

Caf, Yasemin, Maaşoğlu, Yelis, Valipour, Ebrahim, \& Arikan, Burhan. Production and characterization of novel cold-active, $\mathrm{pH}$ tolerant and detergentstable: $\alpha$-amylase from a psychrotrophic bacterium from soil samples. New Biotechnology, 29, Supplement, S82. http://dx.doi.org/10.1016/j.nbt.2012.08.227 Claus, H., \& Decker, H. (2006). Bacterial tyrosinases. Systematic and Applied Microbiology, 29(1), 3-14. http://dx.doi.org/10.1016/j.syapm.2005.07.012

Cura, D Ercili, Lille, M, Partanen, R, Kruus, K, Buchert, J, \& Lantto, R. (2010).

Effect of Trichoderma reesei tyrosinase on rheology and microstructure of acidified milk gels. International dairy journal, 20(12), 830-837. http://dx.doi.org/10.1016/j.idairyj.2010.06.008

Dalfard, Arastoo Badoei, Khajeh, Khosro, Soudi, Mohammad Reza, NaderiManesh, Hossein, Ranjbar, Bijan, \& Sajedi, Reza Hassan. (2006). Isolation and biochemical characterization of laccase and tyrosinase activities in a novel melanogenic soil bacterium. Enzyme and microbial technology, 39(7), 14091416. http://dx.doi.org/10.1016/j.enzmictec.2006.03.029

Dastager, S. G., Li, W. J., Dayanand, A., Tang, S. K., Tian, X. P., Zhi, X. Y., Jiang, C. L. (2006). Seperation, identification and analysis of pigment (melanin) production in Streptomyces. African Journal of Biotechnology, 5(11), 1131-1134 Decker, H., \& Tuczek, F. (2000). Tyrosinase/catecholoxidase activity of hemocyanins: structural basis and molecular mechanism. Trends in Biochemical Sciences, 25(8), 392-397. http://dx.doi.org/10.1016/s0968-0004(00)01602-9

El-Shora, Hamed M, \& Metwally, M. (2008). Use of Tyrosinase Enzyme from Bacillus thuringiensis for the Decontamination of Water Polluted with Phenols. Biotechnology, 7(2). http://dx.doi.org/10.3923/biotech.2008.305.310

Espín, Juan Carlos, van Leeuwen, Jeroen, \& Wichers, Harry J. (1999). Kinetic study of the activation process of a latent mushroom (Agaricus bisporus) tyrosinase by serine proteases. Journal of agricultural and food chemistry, 47(9), 3509-3517. http://dx.doi.org/10.1021/jf9813539

Fairhead, M., \& Thony-Meyer, L. (2010). Cross-linking and immobilisation of different proteins with recombinant Verrucomicrobium spinosum tyrosinase. $\begin{array}{lll}\text { Journal of } \quad \text { Biotechnology, } & \text { 546-551. }\end{array}$ http://dx.doi.org/10.1016/j.jbiotec.2010.10.068

Franciscon, Elisangela, Grossman, Matthew James, Paschoal, Jonas Augusto Rizzato, Reyes, Felix Guillermo Reyes, \& Durrant, Lucia Regina. (2012) Decolorization and biodegradation of reactive sulfonated azo dyes by a newly isolated Brevibacterium sp. strain VN-15. SpringerPlus, 1(1), 37 http://dx.doi.org/10.1186/2193-1801-1-37

Freddi, G., Anghileri, A., Sampaio, S., Buchert, J., Monti, P., \& Taddei, P. (2006). Tyrosinase-catalyzed modification of Bombyx mori silk fibroin: Grafting of chitosan under heterogeneous reaction conditions. Journal of Biotechnology, 125(2), 281-294. http://dx.doi.org/10.1016/j.jbiotec.2006.03.003

Gandía-Herrero, Fernando, Jiménez-Atiénzar, Mercedes, Cabanes, Juana, GarcíaCarmona, Francisco, \& Escribano, Josefa. (2005). Differential activation of a latent polyphenol oxidase mediated by sodium dodecyl sulfate. Journal of agricultural and food chemistry, 53(17), 6825-6830. http://dx.doi.org/10.1021/jf050505e

Hernandez-Romero, D., Solano, F., \& Sanchez-Amat, A. (2005). Polyphenol oxidase activity expression in Ralstonia solanacearum. Applied and $\begin{array}{llll}\text { Environmental } & \text { Microbiology, } & 71(11), & 6808-6815\end{array}$ http://dx.doi.org/10.1128/aem.71.11.6808-6815.2005

Howard, Richard J, \& Ferrari, Margaret A. (1989). Role of melanin in appressorium function. Experimental Mycology, 13(4), 403-418. http://dx.doi.org/10.1016/0147-5975(89)90036-4

Ito, Masaaki, \& Inouye, Kuniyo. (2005). Catalytic Properties of an Organic Solvent-Resistant Tyrosinase from Streptomyces sp. REN-21 and Its High-Level Production in E. coli. Journal of biochemistry, 138(4), 355-362. http://dx.doi.org/10.1093/jb/mvi150

Kohashi, P. Y., Kumagai, T., Matoba, Y., Yamamoto, A., Maruyama, M., \& Sugiyama, M. (2004). An efficient method for the overexpression and purification of active tyrosinase from Streptomyces castaneoglobisporus. Protein Expression and Purification, 34(2), 202-207. http://dx.doi.org/10.1016/j.pep.2003.11.015

Kong, K. H., Hong, M. P., Choi, S. S., Kim, Y. T., \& Cho, S. H. (2000). Purification and characterization of a highly stable tyrosinase from Thermomicrobium roseum. Biotechnology and Applied Biochemistry, 31, 113 118. http://dx.doi.org/10.1042/ba19990096

Kumar, C. G., Mongolla, P., Pombala, S., Kamle, A., \& Joseph, J. (2011) Physicochemical characterization and antioxidant activity of melanin from a novel strain of Aspergillus bridgeri ICTF-201. Letters in Applied Microbiology, 53(3), 350-358. http://dx.doi.org/10.1111/j.1472-765x.2011.03116.x 
Liu, N., Zhang, T., Wang, Y. J., Huang, Y. P., Ou, J. H., \& Shen, P. (2004). A heat inducible tyrosinase with distinct properties from Bacillus thuringiensis. Letters in Applied Microbiology, 39(5), 407-412. http://dx.doi.org/10.1111/j.1472-765x.2004.01599.x

Lopez-Serrano, D., Sanchez-Amat, A., \& Solano, F. (2002). Cloning and molecular characterization of a SDS-activated tyrosinase from Marinomonas mediterranea. Pigment Cell Research, 15(2), 104-111. http://dx.doi.org/10.1034/j.1600-0749.2002.10068.x

Marino, S. M., Fogal, S., Bisaglia, M., Moro, S., Scartabelli, G., De Gioia, L. Bubacco, L. (2011). Investigation of Streptomyces antibioticus tyrosinase reactivity toward chlorophenols. Archives of Biochemistry and Biophysics, 505(1), 67-74. http://dx.doi.org/10.1016/j.abb.2010.09.019

McMahon, A. M., Doyle, E. M., Brooks, S., \& O'Connor, K. E. (2007) Biochemical characterisation of the coexisting tyrosinase and laccase in the soil bacterium Pseudomonas putida F6. Enzyme and Microbial Technology, 40(5), 1435-1441. http://dx.doi.org/10.1016/j.enzmictec.2006.10.020

Michalik, J., Emilianowicz-Czerska, W., Switalski, L., \& RaczynskaBojanowska, K. (1975). Monophenol monooxygenase and lincomysin biosynthesis in Streptomyces lincolnensis. Antimicrob Agents Chemother, 8(5), 526-531. http://dx.doi.org/10.1128/aac.8.5.526

Philipp, Stephan, Held, Thomas, \& Kutzner, Hans J. (1991). Purification and characterization of the tyrosinase of Streptomyces michiganensis DSM 40015. Journal of basic microbiology, 31(4), 293-300. http://dx.doi.org/10.1002/jobm.3620310412

Pinero, S., Rivera, J., Romero, D., Cevallos, M. A., Martinez, A., Bolivar, F., \& Gosset, G. (2007). Tyrosinase from Rhizobium etli is involved in nodulation efficiency and symbiosis-associated stress resistance. Journal of Molecular Microbiology and Biotechnology, 13(1-3), 35-44. http://dx.doi.org/10.1159/000103595

Rani, Nisha, Joy, Beena, \& Abraham, T Emilia. (2007). Cell suspension cultures of Portulaca grandiflora as potent catalysts for biotransformation of L-tyrosine into L-DOPA, an anti-Parkinson's drug. Pharmaceutical Biology, 45(1), 48-53 http://dx.doi.org/10.1080/13880200601026341

Rao, K. R. S. S., Tripathy, N. K., Rao, D. S., \& Prakasham, R. S. (2013) Production, Characterization, Catalytic and Inhibitory activities of Tyrosinase. Research Journal of Biotechnology, 8(1), 83-95.

Raval, Komal M, Vaswani, Pooja S, \& Majumder, DR. (2012)

Biotransformation of a single amino acid L tyrosine into a bioactive molecule LDOPA. Int J Sci Res, 2, 2250-3153.

Selinheimo, Emilia, Gasparetti, Chiara, Mattinen, Maija-Liisa, Steffensen, Charlotte L, Buchert, Johanna, \& Kruus, Kristiina. (2009). Comparison of substrate specificity of tyrosinases from Trichoderma reesei and Agaricus bisporus. Enzyme and Microbial Technology, 44(1), 1-10. http://dx.doi.org/10.1016/j.enzmictec.2008.09.013

Seo, S. Y., Sharma, V. K., \& Sharma, N. (2003). Mushroom tyrosinase: Recent prospects. Journal of Agricultural and Food Chemistry, 51(10), 2837-2853. http://dx.doi.org/10.1021/jf020826f

Surwase, S.N., Patil, S.A., Apine, O.A., Jadhav, J.P. (2012). Efficient microbial conversion of L-tyrosine to L-DOPA by Brevundimonas sp. SGJ. Appl Biochem Biotechnol 167:1015-28. http://dx.doi.org/10.1007/s12010-012-9564-4

Shuster, V., \& Fishman, A. (2009). Isolation, Cloning and Characterization of a Tyrosinase with Improved Activity in Organic Solvents from Bacillus megaterium. Journal of Molecular Microbiology and Biotechnology, 17(4), 188200. http://dx.doi.org/10.1159/000233506

Wittenberg, C, \& Triplett, EL. (1985). A detergent-activated tyrosinase from Xenopus laevis. II. Detergent activation and binding. Journal of Biological Chemistry, 260(23), 12542-12546.

$\mathrm{Xu}$, D. Y., Chen, J. Y., \& Yang, Z. (2012). Use of cross-linked tyrosinase aggregates as catalyst for synthesis of L-DOPA. Biochemical Engineering Journal, 63, 88-94. http://dx.doi.org/10.1016/j.bej.2011.11.009

Zanjani Sorouri, R., Mir-Esmaili, S. M., Latifi, A.M, \& Valipour, E. (2009) Isolation and identification of a type strain bacteria with the highest ability to produce organophosphorus acid anhidrase. Journal of Mazandaran University of Medical Sciences, 18(68). 